\title{
Enhancing teaching and learning in higher education through formative assessment: Teachers' Perceptions
}

\author{
Shamsiah Banu Mohamad Hanefar (i) 1,*, Nusrat Zerin Anny ${ }^{(i)}$, Md. Sajedur Rahman (iD)
}

${ }^{1}$ Centre for Academic Partnerships \& Engagement (CAPE), University of Nottingham Malaysia, Malaysia

${ }^{2}$ Department of Sociology, Rajshahi College, Rajshahi, Bangladesh

${ }^{3}$ Department of Economics, Rajshahi College, Rajshahi, Bangladesh

\author{
ARTICLE HISTORY \\ Received: June 01, 2021 \\ Revised: Oct. 12, 2021 \\ Accepted: Jan. 13, 2022 \\ Keywords: \\ Formative assessment, \\ Teachers' perceptions, \\ Higher education.
}

\begin{abstract}
A good assessment system is one of the preconditions for quality education. Formative assessment is comparatively an emerging idea to assess the students throughout the academic year with the intention to identify and overcome the weaknesses of the students and enhance their learning outcome. Taking these into account, this study attempted to explore the teachers' perceptions of the use of formative assessment in enhancing teaching and learning in Bangladesh higher education. A mixed-method study was employed with survey and semi-structured interview as the data collection methods. 100 participants were randomly (simple random) selected for the survey, and 6 participants were purposively selected for the interviews. For analysing the data, descriptive analysis and content analysis were used. The findings of the study revealed majority of the participants agreed that formative assessment is crucial to enhance teaching and learning in Bangladeshi colleges. Nonetheless, there are some challenges like - teachers' biasness, shortage of teachers, large class, poor infrastructure, insufficient power supply, and heavy workload of the teachers. As a whole, this study will provide a fundamental ground for future research in formative assessment in Bangladeshi colleges specifically and for comparative study with other higher education institutions globally.
\end{abstract}

\section{INTRODUCTION}

Assessment has always been an important part of education that has a great impact on shaping the students' learning (Azim, 2014). One of the prerequisites for a good educational system is a good assessment system. (Bjornsrud \& Engh, 2012). Assessment is a term used to describe a method in which teachers collect information about the teaching-learning environment, such as the students' level of knowledge and comprehension (Ngendahayo, 2014), is a key component of teaching and learning in higher education (Gikandi, Morrow, \& Davis, 2011). According to William (2014), in many educational institutions, students are assessed at the completion of an academic year (summative assessment) even though evolving idea of a new assessment system (formative assessment) has been advocated by many scholars (Black \& William, 2009; Sadler, 1998; Yorke, 2003). Formative assessment ensures information and feedback during the

\footnotetext{
*CONTACT: Shamsiah Banu Mohamad Hanefar $\$ Shamsiah.Banu@nottingham.edu.my, shbanu21@gmail.com 를 Centre for Academic Partnerships \& Engagement (CAPE), University of Nottingham Malaysia, Malaysia
} 
learning process, while summative assessment occurs after the learning process has been completed and provides feedback and information regarding the process (Figa, Tarekegne, \& Kebede, 2020; Paul et al., 2016). The primary focus of this research is on formative assessment and its effect on teaching-learning practises.

In recent years, all over the world, formative assessment has become the preferred form of assessment compared to summative assessment (Ozan \& Kincal, 2018). Likewise, The World Bank directly links high-quality, formative assessment to better outcomes on standardised tests, and links better learning outcomes to increased national prosperity (Clarke, 2012). In-line with this need, Bangladesh is also experiencing a shift from summative to formative assessment for more than last one decade (Rahman et al., 2021), and formative assessment is gradually becoming more important in this context. The country has already started formative assessment in the junior secondary level named School Based Assessment in order to assess learners' holistic development since 2007 (Begum \& Farooqui, 2008; Rahman et al., 2021). Having said that, the assessment system in higher education is still poor in Bangladesh (Mamun-ur-Rashid \& Rhman, 2017; Rahman et al., 2019; Ahmed et al., 2021), where there is little or no place for effective on-going assessment and appropriate feedback system.

At present, Bangladesh is struggling to enhance the quality of education at every level (Mamunur-Rashid \& Rhman, 2017). Its higher educational institutions are passing through a very hard time as their rankings are poor even in the context of South Asian Countries (Mahmud, 2019). In terms of assessment, higher educational institutions in the country still depend mostly on the traditional summative assessment as the main way of measuring the students' learning outcomes (Rahman et al., 2019). What is more, Muhammad et al.'s (2019) study has revealed that a large number of Bangladeshi colleges do not have a clear idea about what formative assessment is. As a result, students just memorise their course materials for the year-end examination and get their certificates (Muhammad et al., 2019). Here, it should also be noted that research on the use of formative assessment in Bangladeshi higher education is also scarce in number. This means that many issues related to formative assessment in higher education of Bangladesh are still unexplored. This study, therefore, has attempted to fill the knowledge gap regarding formative assessment in Bangladeshi higher education sector by exploring teachers' perception on the use of formative assessment to enhance teaching and learning practices.

The concept of formative assessment arose in the 1930s and 1940s as a result of cognitive and constructivist learning theories in line with the ideas of feedback and development (Roos \& Hamilton, 2005). It is a pre-determined method for assessing students' learning status that is used by teachers to tailor their instructional strategies or by students to adapt their learning strategies (Barney \& McCowans, 2009). Furthermore, it denotes a form of assessment that judges the students on the basis of their performance with the intention to give them constructive feedback aiming at the enhancement of learning outcomes (Sadler, 1998). This type of assessment is designed with the intention to explore students' intelligence or knowledge, permitting teachers to understand students' prior knowledge, and select the more appropriate teaching-learning strategy for them (Bransford et al., 1999). Clarck (2012) and Ngendahayo (2014) argued that formative assessment is considered as both 'learning for assessment' and 'learning as assessment' with the intention to promote students' learning and enhance their critical thinking respectively. However, in Bangladesh most teachers do not differentiate between formative and summative assessments for grading purpose, they occasionally use summative assessments for formative purposes. This supports William's (2000) findings, which claim that in most countries, few teachers are able or willing to use parallel assessment systems - one is for summative purposes, and the other is for formative purposes. As a result, teachers often replicate and duplicate the assessment process. 
Many scholars claim that the effect of formative assessment on teaching and learning is positive (Winstone \& Millward, 2012; Yorke, 2003; Young \& Jackman, 2014). This type of assessment can help both teachers and students in a variety of ways. (López-Pastor \& Sicilia-Camacho, 2017; Wang et al., 2006; Winstone \& Millward, 2012). Rather than producing just a competent individual in a specific field, one of the current priorities of higher education is to develop highly skilled students with a variety of attributes such as problem-solving capacity, analytical thinking, stress management, and so on. (Dochy et al., 1999). In line with this, the Organization for Economic Cooperation and Development (OECD) recommended a shift from summative to formative evaluation in 2009, citing successful assessment as one of the most significant factors in improving learning outcomes (Bjornsrud \& Engh, 2012). In their study, Harlen \& James (1997) argue that the real learning is something that comes through human interaction or/and exchange of ideas and actions in the real-life situation. In this regard, a study by Umer and Omer (2015) found that formative assessment helps students to grow as an independent learner'. Dochy et al. (1999) also argue that formative assessment is a more effective way of assessing students in order to prepare them for the current competitive world.

In terms of its effectiveness, Black and William (1998) found that formative assessment is effective in almost all kinds of educational settings (Sadler, 1998; Umer \& Omer, 2015), but some scholars argue that formative assessment is more effective for higher education (Bennett, 2011; Dochy et al., 1999). Ruiz-Primo (2011) found that informal formative assessment is more effective in terms of constructive learning. In fact, this type of assessment can be very helpful for both teachers and students (Bransford et al., 1999). In addition, several prior studies have also proven the effectiveness of different innovative designs or strategies of formative assessment in enhancing the students' achievement in terms of learning outcome (Black \& Wiliam, 1998; Winstone \& Millward, 2012; Yorke, 2003; Young \& Jackman, 2014). In terms of teachers' perceptions on the effectiveness of formative assessment, several studies have found that most of the teachers perceive formative assessment positively (Dijksterhuis et al., 2013; López-Pastor \& Sicilia-Camacho, 2017; Sach, 2012; Winstone \& Millward, 2012; Young \& Jackman, 2014). Based on the existing literature, it is clear that formative assessment has the potential to enhance the teaching-learning process.

In spite of a huge number of positive writings on the effectiveness of formative assessment, there are a considerable number of oppositions also (Antoniou \& James, 2013). Problem of applying formative assessment starts from the issue of its definition as it is not a well-defined concept (Bennett, 2011). In this regard, the concept of formative assessment and one of its central elements, which is feedback, are used for different purposes in different papers (Antoniou \& James, 2013; Bennett, 2011). This ambiguity affects the practical assessment scenario by creating misunderstanding as different people have different understandings about the same concept (Klenowski, 2009). Apart from that, the quality of feedback can also affect the whole process of assessment and learning (Dijksterhuis et al., 2013; Umer \& Omer, 2015). Furthermore, the efficiency of this form of assessment in higher education is not clear (Yorke, 2003). In order to get the best result from formative assessment, a precise definition of the concept should be developed to reduce the ambiguities related to what formative assessment refers to (Bennett, 2011).

In addition, there are also some preconditions of implementing formative assessment likemotivated teacher; effective classroom practice; favourable classroom environment; long-term relation based on commitment between the learner and the educator, and the need for necessary tools (Antoniou \& James, 2013; Dijksterhuis et al., 2013). As claimed by Black \& Wiliam (2003), the lack of these necessary preconditions could become the major challenge in implementing formative assessment. 
The existing tension between summative and formative assessment also affects the frequency of implementing formative assessment (Sach, 2012). Recent study by Figa et al. (2020) has listed several factors that may hinder the use of formative assessment. According to them, the lack of learning aids, teachers' competence and large class size are categorised as the most challenging factor while time constraint, impact of summative assessment and shortage of classroom facilities are considered as medium challenging factors. In addition, factors such as teachers' negative attitude, enhanced workload, absence of structured assessment guideline, and students' negative attitude have been found to be the moderate challenging factors in the implementation of formative assessment in higher education. Similar challenges have also been found in the papers of Awasthi, and Chaudhary (2015), Sach (2012), Sharma et al. (2015), and López-Pastor and Sicilia-Camacho (2017). Furthermore, some argue that formative assessment can create biasness (Antoniou \& James, 2013).

In addition, Young and Jackman (2014) also found negative attitudes of the teachers due to the lack of confidence, incompetency, fear of workload, pressure from guardians of the students or administration, time, and resource constraints. The same study also suggests that in some cases, teachers consider formative assessment as a positive measure but do not apply this in their class because of the aforesaid reasons. In fact, some teachers refuse to apply formative assessment as they believe that their students should be assessed just as they were assessed by their teachers in their student life (López-Pastor \& Sicilia-Camacho, 2017). In a nutshell, the above review suggests that there is a continuous debate on the effectiveness of formative assessment, which, in fact, is essential for the improvement of formative assessment practices. Overall, while some negative attitudes towards formative assessment have been documented in numerous past studies, it is also worth reiterating that the majority of teachers have demonstrated positive attitudes towards the approach.

The higher education of Bangladesh is passing through a lot of challenges like scarcity of efficient teachers, shortage of classroom, absenteeism, problems between the teachers and the students, and political pressure (Monem \& Baniamin, 2010; Muhammad et al., 2019). Due to these issues, the country is struggling to ensure the quality of education in tertiary level (Rabiul, 2014). In most higher education institutions of Bangladesh, academic performance of a student is judged predominantly on the basis of a final examination (Shahidul, 2016). In their study, Bhuiyan \& Hossain, (2017) recommended that the traditional classroom practice should be changed towards interactive learning in order to engage the students in different activities throughout the academic year. The teacher-student relations should also be improved through frequent interaction (Bhuiyan \& Hossain, 2017). Within this kind of situation, it is not easy to implement effective formative assessment in the higher education of Bangladesh. Nonetheless, the government is implementing formative assessment in the secondary level institutions, where many teachers appreciate this as a way of getting better learning outcome (Begum \& Farooqui, 2008; Harlen \& James, 1997). Formative assessment has also been implemented successfully in the medical education of Bangladesh (Riaz et al., 2015).

As a whole, the above discussion shows that formative assessment is not totally absent in the Bangladeshi education system, but more issues need to be explored so that formative assessment can be implemented more effectively in this context. Drawing on this need, we have taken the initiative to explore teachers' perceptions toward formative assessment and its role in enhancing the teaching and learning in Bangladeshi higher education.

\section{METHOD}

A mixed-method approach was adopted by combining qualitative and quantitative approaches with the intention to get a complete picture of the use of formative assessment to enhance teaching and learning based on a group of Bangladeshi college teachers' perspectives. This 
mixed - method has allowed the authors to triangulate the data and validate the data collected. For the data collection process, the study began with its quantitative strand, where a survey was administered. Next, the study proceeded with its qualitative strand, where a series of semistructured interview sessions aiming to elicit in-depth information about teachers' perceptions on the use of formative assessment, were conducted. Prior to data collection, an information sheet describing the background and purpose of the study was presented and the consent was obtained from all the participants and the principal of a selected government college (RJ College).

This study has been carried out within the context of RJ College (one of the researchers' workplace) which is a well-known government college in Bangladesh. There are 250 teachers teaching in this college. Majority of the teachers are still using summative assessment to asses their students. Nonetheless, many of them have gradually started to use formative assessment tools such as class test, questioning, quiz, in-class competition, presentation, and workshop.

A total of 106 teachers from RJ College, Bangladesh have participated in this study. For the selection process, 100 teachers (among the 250 teachers teaching at the respective college) were first selected randomly using simple random sampling technique to participate in the survey. Then, six teachers from the same college were purposively selected for the subsequent semistructured interviews. Teachers who participated in the survey were excluded from the interviews to avoid biasness in their answers. In terms of working experience, $78 \%$ of the survey respondents had worked in at least one other college before their service at this participating college. Among the interview participants, five respondents had worked in at least one other college prior to joining this participating college.

For the survey, a structured questionnaire containing 12 items were developed. To measure the teachers' perceptions and current practices of formative assessment, a 5-point Likert scale (from strongly disagree to strongly agree) was used. A pilot study was conducted for this survey with 40 participants and the Cronbach's Alpha test was performed through SPSS v 25, where the alpha value is 0.746 . All quantitative data were analysed with SPSS v 25 (descriptive analysis was used). For the semi-structured interviews, an interview schedule containing 10 questions was used to guide the data collection process. To ensure its validity and reliability, two interview sessions were conducted to pilot the instrument (interview schedule) that had been developed for this study. Apart from that, the interview schedule was checked by two experts. In analysing the qualitative data, a content analysis had been conducted. Four main stages of qualitative content analysis have been used in this study (Figure 1): the decontextualisation, the recontextualisation, the categorisation, and the compilation (Bengtsson, 2016).

Figure 1. A qualitative content analysis adapted from Bengtsson (2016).

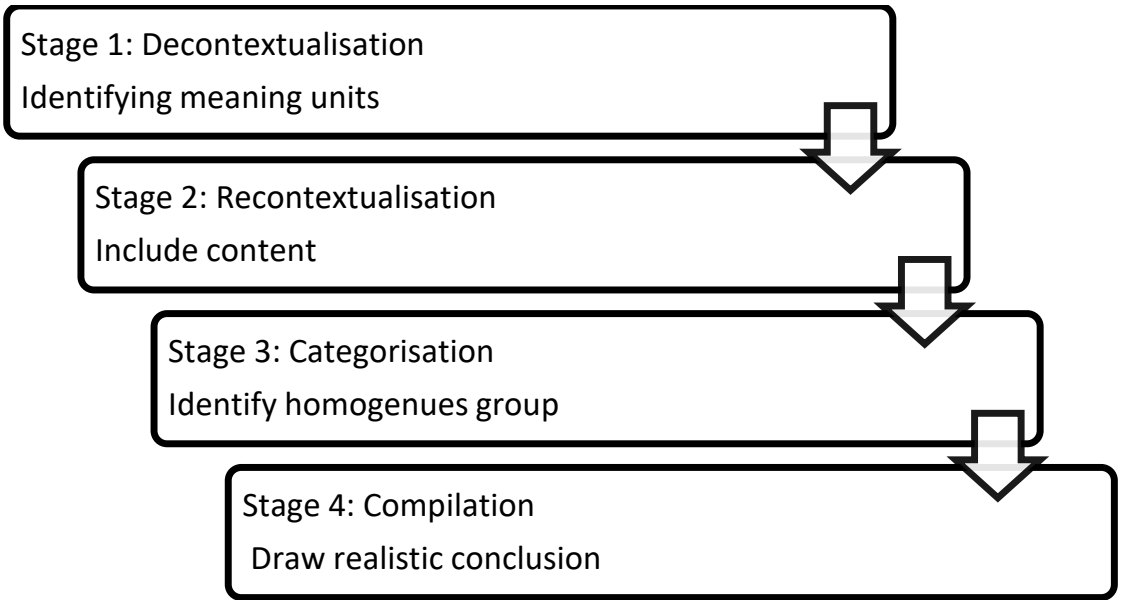




\section{RESULTS / FINDINGS}

\subsection{Quantitative results and analysis}

The results of the quantitative study depicted a mixed outcome. Majority of the respondents strongly agreed and agreed that formative assessment is important but currently it is not being emphasised as a main form of assessment throughout the academic year. Besides, there are some who still believe that formative assessment would not be able to provide a good quality feedback. Nonetheless, majority of them perceived formative assessment as a form of assessment that enhance students' engagement, attentiveness and interest. Furthermore, it allows students to inquire in-depth knowledge and decrease their absenteeism, and provides teachers to assess the gradual development of the students' learning outcome. Details of the results are provided in Table 1 below:

Table 1. Quantitative results on teachers' perception on the role of formative assessment to enhance teaching and learning in higher education.

\begin{tabular}{|c|c|c|c|c|c|c|c|c|}
\hline No & Statement & 1 & 2 & 3 & 4 & 5 & Mean & $\begin{array}{l}\text { Standard } \\
\text { Deviation }\end{array}$ \\
\hline 1 & $\begin{array}{l}\text { Class performance based formative as- } \\
\text { sessment makes the students more at- } \\
\text { tentive in their class. }\end{array}$ & 0 & 3 & 14 & 38 & 45 & 4.25 & 0.81 \\
\hline 2 & $\begin{array}{l}\text { Formative assessment helps to engage } \\
\text { the students with their study. }\end{array}$ & 0 & 4 & 6 & 52 & 38 & 4.24 & 0.74 \\
\hline 3 & $\begin{array}{l}\text { Formative assessment allows the } \\
\text { teachers to assess gradual develop- } \\
\text { ment status of the learning outcome. } \\
\end{array}$ & 0 & 0 & 10 & 56 & 34 & 4.24 & 0.62 \\
\hline 4 & $\begin{array}{l}\text { Formative assessment allows the stu- } \\
\text { dents to acquire in-depth knowledge. }\end{array}$ & 3 & 3 & 11 & 42 & 41 & 4.15 & 0.95 \\
\hline 5 & $\begin{array}{l}\text { Percentage of marks in final grading } \\
\text { through formative assessment contrib- } \\
\text { utes to decrease absenteeism. }\end{array}$ & 1 & 5 & 15 & 37 & 42 & 4.14 & 0.92 \\
\hline 6 & $\begin{array}{l}\text { Formative assessment strategies make } \\
\text { their study interesting to the students. }\end{array}$ & 0 & 9 & 10 & 51 & 30 & 4.02 & 0.88 \\
\hline 7 & $\begin{array}{l}\text { Formative assessment is the most im- } \\
\text { portant type of assessment. }\end{array}$ & 9 & 12 & 13 & 54 & 12 & 3.48 & 1.13 \\
\hline 8 & $\begin{array}{l}\text { Formative assessment happens all } \\
\text { through the academic year. }\end{array}$ & 4 & 26 & 13 & 35 & 22 & 3.45 & 1.21 \\
\hline 9 & $\begin{array}{l}\text { Political/other pressure affects the } \\
\text { system of grading through formative } \\
\text { assessment. }\end{array}$ & 7 & 22 & 18 & 27 & 26 & 3.43 & 1.29 \\
\hline 10 & $\begin{array}{l}\text { Formative assessment provides qual- } \\
\text { ity feedback. }\end{array}$ & 9 & 21 & 9 & 49 & 12 & 3.34 & 1.20 \\
\hline 11 & $\begin{array}{l}\text { The current practice of formative as- } \\
\text { sessment is satisfactory. }\end{array}$ & 2 & 25 & 29 & 32 & 12 & 3.27 & 1.03 \\
\hline 12 & $\begin{array}{l}\text { Teacher's biasness is a problem in } \\
\text { case of grading through formative as- } \\
\text { sessment. }\end{array}$ & 15 & 29 & 24 & 16 & 16 & 2.89 & 1.30 \\
\hline
\end{tabular}

Average mean score: 3.74

(The items were re-arranged in a descending order to ease the discussion.)

The average mean score for all the 12 items is 3.74. Among all the 12 items, for 6 items, the mean value is less than the average mean score (Item 7 to 12). These results indicate that the teachers put less emphasis on the importance of the formative assessment and the practice is limited in the context of higher education in Bangladesh as they maybe feel more comfortable 
in the traditional method of assessment which is the summative assessment, i.e. final examination. This statement is supported by findings of other researchers (Muhammad et al., 2019; Rahman et al., 2019; Rabiul, 2014; Shahidul, 2016).

For the other remaining 6 items (Item 1 to 6 ), the mean value is higher than the average mean score. This clearly shows that teachers were aware about the benefits of formative assessment and they demonstrated positive perceptions on this type of assessment. Studies done by Dijksterhuis et al (2013), López-Pastor and Sicilia-Camacho (2017), Sach (2012), Winstone and Millward (2012), and Young and Jackman (2014) also indicate that teachers perceived formative assessment positively as it leads to many positive outcomes such as enhancing students' engagement and interest in learning, allows students to acquire in-depth knowledge, and increase class attendance.

\subsection{Qualitative Findings and Analysis}

Findings of qualitative analysis have revealed different themes related to the teachers' perceptions on formative assessment. The themes are: 1) Teacher's prior understanding of formative assessment in higher education, 2) current practice of formative assessment, 3) teachers' attitudes towards formative assessment, 4) importance of implementing formative assessment, and 5) challenges in implementing formative assessment. Table 2 outlined the details of these findings. 
Table 2. Qualitative finding on teachers' perception on the role of formative assessment (FA) to enhance teaching and learning in higher education.

\begin{tabular}{|c|c|c|c|c|}
\hline Meaning Unit & Condensed Meaning Unit & Code & Category & Theme \\
\hline $\begin{array}{l}\text { "Students can easily get prepared for their final examination } \\
\text { through this type of assessment prior to the examination. As a } \\
\text { result, they don't feel very much pressured before their final } \\
\text { examination" (Teacher 1) }\end{array}$ & $\begin{array}{l}\text { Students able to prepare for final } \\
\text { examination with less pressure }\end{array}$ & $\begin{array}{l}\text { Less pressured exam } \\
\text { preparation }\end{array}$ & Benefit of FA & \multirow{5}{*}{$\begin{array}{l}\text { Teacher's prior } \\
\text { understanding }\end{array}$} \\
\hline \multirow[t]{2}{*}{$\begin{array}{l}\text { "Students get the opportunity to enhance their problem-solving } \\
\text { skills through effective application of formative assessment" } \\
\text { (Teacher 4) }\end{array}$} & $\begin{array}{l}\text { Student able to enhance their } \\
\text { problem solving skills }\end{array}$ & $\begin{array}{l}\text { Enhancement of } \\
\text { problem solving skill }\end{array}$ & Benefit of FA & \\
\hline & & $\begin{array}{l}\text { Enhancement of } \\
\text { student learning }\end{array}$ & Benefit of FA & \\
\hline \multirow[t]{2}{*}{$\begin{array}{l}\text { "It enhances the learning of the students, as it makes them more } \\
\text { confident and finally make them able prepare them to cope with the } \\
\text { competitive real world" (Teacher } 6 \text { ) }\end{array}$} & $\begin{array}{l}\text { Enhance student learning, build } \\
\text { student's confident; coping with } \\
\text { competitive real world }\end{array}$ & $\begin{array}{l}\text { To build student } \\
\text { confident level }\end{array}$ & Benefit of FA & \\
\hline & & $\begin{array}{l}\text { To cope with real life } \\
\text { scenario }\end{array}$ & & \\
\hline $\begin{array}{l}\text { "I use different types of FA such as class test, questioning, quiz, } \\
\text { competition, presentation, workshop, and symposium" (Teacher 5) }\end{array}$ & $\begin{array}{l}\text { Different types of FA are being } \\
\text { used; class test, questioning, quiz, } \\
\text { competition, presentation, } \\
\text { workshop, and symposium. }\end{array}$ & $\begin{array}{l}\text { Different types of FA } \\
\text { in-use }\end{array}$ & $\begin{array}{l}\text { Types of FA in } \\
\text { practice }\end{array}$ & \multirow{3}{*}{ Current practice } \\
\hline $\begin{array}{l}\text { "I believe many of us use formative assessment as a mean for } \\
\text { grading and adding the marks rather than providing feedback to the } \\
\text { students" (teacher 2) }\end{array}$ & $\begin{array}{l}\text { FA is used as a mean for grading } \\
\text { and adding the marks rather than } \\
\text { providing feedback to the students }\end{array}$ & $\begin{array}{l}\text { The use of FA to grade } \\
\text { rather than providing } \\
\text { feedback }\end{array}$ & $\begin{array}{l}\text { Assessment of } \\
\text { learning rather than } \\
\text { assessment for } \\
\text { learning }\end{array}$ & \\
\hline $\begin{array}{l}\text { "The main form of assessment is still summative assessment (SA), } \\
\text { which is that is, a final examination of } 80 \% \text { of total marks for each } \\
\text { course after ending an academic year. The remaining } 20 \% \text { of the } \\
\text { marks comes from attendance }(5 \%) \text { and in-course assessment } \\
(15 \%) \text { such as class test, written assignment, oral presentation, } \\
\text { poster presentation, and etcetera" (Teacher } 3 \text { ) }\end{array}$ & $\begin{array}{l}\text { SA contributes } 80 \% \text { of the } \\
\text { grading meanwhile } 20 \% \text { is } \\
\text { allocated for FA. }\end{array}$ & $\begin{array}{l}\text { The purpose of SA and } \\
\text { FA are for grading }\end{array}$ & $\begin{array}{l}\text { Assessment of } \\
\text { learning rather than } \\
\text { assessment for } \\
\text { learning }\end{array}$ & \\
\hline
\end{tabular}




\begin{tabular}{|c|c|c|c|c|}
\hline $\begin{array}{l}\text { "On the spot class test is arranged whenever necessary to keep the } \\
\text { learning momentum and attention of the students in class" (Teacher } \\
\text { 1) }\end{array}$ & $\begin{array}{l}\text { On the spot class test to keep the } \\
\text { learning momentum and attention } \\
\text { of the students }\end{array}$ & $\begin{array}{l}\text { Formative assessment } \\
\text { as a tool for student } \\
\text { engagement }\end{array}$ & $\begin{array}{l}\text { Assessment as } \\
\text { learning }\end{array}$ & \\
\hline $\begin{array}{l}\text { "Actually, we work in a rigid system structure where there is a } \\
\text { little chance to change the system. At present, we are adding the } \\
\text { marks from in-course examination to the final marks of our } \\
\text { students" (Teacher 6). }\end{array}$ & $\begin{array}{l}\text { The work place system is rigid, } \\
\text { little room for improvement. The } \\
\text { marks allocated for in class } \\
\text { activities are added to final exam } \\
\text { marks for the final grading. }\end{array}$ & $\begin{array}{l}\text { The purpose of FA is } \\
\text { for grading }\end{array}$ & $\begin{array}{l}\text { Assessment of } \\
\text { learning }\end{array}$ & \\
\hline $\begin{array}{l}\text { "Some of us, we try to upgrade improve our common practice by } \\
\text { observing the current assessment needs by other advanced } \\
\text { countries" (Teacher 2) }\end{array}$ & $\begin{array}{l}\text { Teachers are taking their own } \\
\text { initiative to learn from best } \\
\text { practices of other advanced } \\
\text { countries. }\end{array}$ & $\begin{array}{l}\text { Teacher initiation to } \\
\text { learn from the best } \\
\text { practices }\end{array}$ & $\begin{array}{l}\text { Continuous learning } \\
\text { and improvement }\end{array}$ & \\
\hline $\begin{array}{l}\text { "We are always improving the formative assessment practices of } \\
\text { my department according to the demands of this era of } \\
\text { globalization. We analyse the assessment systems of the developed } \\
\text { countries and upgrade our assessment system" (Teacher 5) }\end{array}$ & $\begin{array}{l}\text { The formative assessment } \\
\text { practices are being improved by } \\
\text { reviewing and analysing the best } \\
\text { practices of other developed } \\
\text { countries. }\end{array}$ & $\begin{array}{l}\text { The practice of } \\
\text { formative assessment is } \\
\text { improving by } \\
\text { reviewing and } \\
\text { analysing the best } \\
\text { practices }\end{array}$ & $\begin{array}{l}\text { Continuous learning } \\
\text { and improvement }\end{array}$ & \\
\hline $\begin{array}{l}\text { "The progressive and open-minded teachers are very positive and } \\
\text { try to apply formative assessment in their classes as much as } \\
\text { possible" (Teacher 6) }\end{array}$ & $\begin{array}{l}\text { Progressive and open minded } \\
\text { teachers apply formative } \\
\text { assessment frequently. }\end{array}$ & $\begin{array}{l}\text { Progressive and open } \\
\text { minded teacher }\end{array}$ & Positive attitude & \multirow{3}{*}{$\begin{array}{l}\text { Teacher's } \\
\text { attitude }\end{array}$} \\
\hline $\begin{array}{l}\text { "Some teachers are more comfortable with traditional method of } \\
\text { assessment as they are not ready to make a drastic change that } \\
\text { differs from the norm and they resist to a new system of } \\
\text { assessment" (Teacher 5) }\end{array}$ & $\begin{array}{l}\text { Some teachers are habituated with } \\
\text { SA and hesitate to make any } \\
\text { changes. }\end{array}$ & Preference towards SA & Status quo & \\
\hline $\begin{array}{l}\text { In some cases, teachers lose their interest in applying formative } \\
\text { assessment in their classes because of various difficulties like infra- } \\
\text { structural problem, power cut, large classes etcetera that they face } \\
\text { while doing activities" (Teacher 1) }\end{array}$ & $\begin{array}{l}\text { Teachers lost interest to practice } \\
\text { FA because of issues related to } \\
\text { infrastructural problems, power } \\
\text { cuts, large classes etc. }\end{array}$ & $\begin{array}{l}\text { Disadvantages - } \\
\text { Environmental factors }\end{array}$ & Negative attitude & \\
\hline $\begin{array}{l}\text { "Both the standard of education and students' results in the final } \\
\text { examination was were much better than before. (Teacher 4) }\end{array}$ & $\begin{array}{l}\text { Standard of education and } \\
\text { students' results were improved. }\end{array}$ & $\begin{array}{l}\text { FA contribute to } \\
\text { enhance the quality of } \\
\text { instruction and student } \\
\text { outcome }\end{array}$ & $\begin{array}{l}\text { Quality of } \\
\text { instruction }\end{array}$ & Importance \\
\hline
\end{tabular}


"FA allowed us to engage and assess our students throughout the academic year" (Teacher 2)

"It also allowed the students to get in-depth knowledge on their course content and overcome their weaknesses" (Teacher 3 )

"I like to apply FA in my class because I can identify differen needs of the students with different abilities and fulfil them as much as possible" (Teacher 5)

"There is a need to increase the weighting of FA in the overal assessment measure; more quality feedback, and some preconditions for implementing FA successfully in Bangladeshi colleges had to be fulfilled prior to that" (Majority of the teachers)

"The institution should enhance a higher level of transparency among the teachers, and to gain a better support from superior and support staffs are essential for a successful implementation of FA" (Teacher 5 and 6)

(2)

"It is difficult to implement FA in a large class within a short period of a particular lesson" (Teacher 2)
FA allowed teachers to engage and assess students throughout the academic year"
Enhancement of

FA allowed students to gain indepth knowledge of the course content, improve their understanding

FA allows teachers to identify different needs and abilities of the students; provide opportunity for teacher to address them and take the necessary actions

The weighting of FA in the overall assessment measure should be increased and quality feedback is needed.

Some pre-conditions to implement FA should be fulfilled

A higher level of transparency among teachers, support from superior, and assistance from support staff (administration staff) contribute to the successful implementation of FA.

Difficult to implement FA in large class within a short period of a particular lesson student engagement

Continuous assessment

Student able to

improve their

understanding on a

course content

Student outcome

Student engagement

Continuous assessment

In-depth unders tanding of a course content

Teacher able to identify Identification and the different students' rectification of needs and abilities; Students' learning take necess ary actions needs and abilities

To increase the weighting of FA and

Priority on FA with

provide quality feedback

Pre-conditions to

improve the

\section{Pre-conditions to} improve the implementation of implementation of FA FA

A higher level of transparency among teachers, support from

Pre-conditions to improve the

superior, and assistance implementation of from support staff FA (administration staff

\section{Difficulty in implementation due to \\ large class size and}

Large class size short time period 
"Many times when I plan for a FA via multimedia, there will be a power cut or problems with the internet connectivity" (Teacher 4)

"Some of the problems that we faced that hinder us to implement FA successfully in our class are such as resource scarcity, infrastructural issues, shortage of teachers, and heavy work load of the teachers" (Majority of the teachers) challenges such as favouritism and biasness happened while grading the students through formative assessment" (Teacher 3 and

"Sometimes the teachers of Bangladesh tend to over-grade favourite students or under-grade unpopular students. ... I find problems like political pressure, administrative pressure and nepotism as the possible reasons behind teacher's biasness" (Teacher 6)

"In this country, students of different higher educational institutions are largely engaged in political activities. As a result, in many cases teachers of Bangladeshi colleges have to face huge political pressure while grading a politically active student.

Sometimes the pressure comes from the college administration, which can also be the result of due to higher political pressure from a higher authority" (Teacher 6 ) power failure and problems with internet connectivity.

Inability to conduct

formative assessment

due to power failure

and poor internet

Power failure and

poor internet

connectivity.

connectivity.

Resource scarcity,

infrastructural issues

shortage of teachers,

and teacher's heavy

the teachers to implement FA

were resource scarcity,

work load hinder the

successful

implementation of in-

class formative

assessments.

Issue related to cultural

challenges; favouritism and

biasness while grading the

students through formative

Favouritism, Biasness

Cultural challenges

assessment

Bangladeshi teachers tend to

over-grade or under-grade

students based on their popularity Political influence Cultural challenges

and involvement in political

activity.

Bangladeshi teachers are

indirectly pressured to give

good grade to students who are

Resource scarcity, infrastructural es, shortage of

teachers, and

teacher's heavy

work load

engaged in political activity
Political influence Cultural chall enges 
The quantitative results and qualitative findings show a similar pattern of teachers' perceptions on formative assessment. This allows for triangulation to happen to enhance the validity and reliability of this study. Figure 2 shows the triangulation between the two which is discussed in detail in the next section.

Figure 2. Triangulation of quantitative results and qualitative findings based on descriptive analysis and content analysis.

Results/ Findings

are intergrated and interpreted

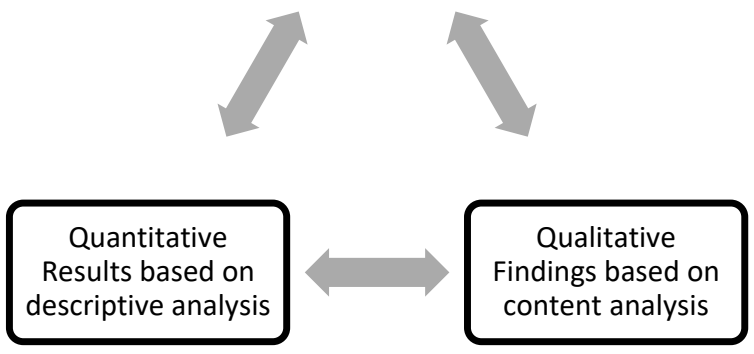

\section{DISCUSSIONS}

\subsection{Teacher's Prior Understanding of Formative Assessment in Higher Education}

From the quantitative results, the three items; formative assessment is the most important type of assessment, it happens all through the academic year, and it provides quality feedback indicate that majority of the teachers have the prior knowledge about what formative assessment is. The findings from the qualitative study also revealed the same. Overall, all the participants considered formative assessment as a very important and useful tool in higher education, where most of them regarded it as the dominant form of assessment. This, as a whole, mirrors the findings of Dochy et al. (1999) and Bennett (2011). Both quantitative and qualitative studies show that the teacher participants acknowledged the benefits that students can gain from formative assessment. Some of the benefits outlined by the participants are enhancement of students' interest in learning and class engagement, and allows students to acquire in-depth knowledge. In line with what had been found in a study by Dochy et al. (1999), the participants also related the use of formative assessment with the development of various qualities among the students such as problem solving skills through effective application of formative assessment. Besides, it also enhances the learning of the students, as it makes them more independent and confident learners, and finally prepare them to cope with the competitive real world (Harlen \& James, 1997; Dochy et al., 1999).

However, despite the positive perceptions of formative assessment, none of the participants believed that it should be used as the only assessment system for higher education in Bangladesh, particularly in the current socio-political condition of the country. All respondents also acknowledged the necessity of summative assessment with some regarded formative assessment as a complementary for summative assessment.

\subsection{Current Practice of Formative Assessment}

From the survey, $44 \%$ of the respondents strongly agreed and agreed that the current practice of formative assessment is satisfactory. This finding is supported by the qualitative findings. In the interviews, all respondents claimed that formative assessment was commonly used in their classrooms even though summative assessment was still the main form of assessment in the participating college. Common examples of formative assessment strategies used by 
majority of them are class test, questioning, quiz, competition, presentation, and workshop. In this context, teachers implemented different strategies depending on the class content, but the most common form of formative assessment was class test, which was practised by all the six interviewees. Muhammad et al. (2019) also found class test as a popular form of formative assessment in their study in Bangladeshi colleges.

Having said that, it is worth mentioning here that the implementation of formative assessment was mainly due to the instructions of the National University of Bangladesh. The practice of formative assessment by the majority of the participants is merely for grading their students, which indicates the assessment of learning. Nonetheless, the essence of formative assessment is not about grading per se, but to provide quality feedback so that students can continue to learn and improve (assessment of learning). According to Crooks (1988, p.468), "Too much emphasis has been placed on the grading function of evaluation and too little on its role in assisting students to learn". For a formative assessment to be effective especially for students' learning, providing feedback is necessary. This is supported by Black and William (1998). Hence, it is essential for Bangladeshi teachers to incorporate feedback in any forms of formative assessment. Formative assessment should provide information about the learning process that teachers can use for instructional decisions and students can use in improving their performance, which motivates students (William, 2011).

Some teachers also try to improve their practice by observing the current teaching and learning needs of other advanced countries. They take initiative to improve the formative assessment practices of their department according to the demands of this era of globalization. Some of the teachers analyse the assessment systems of the developed countries and upgrade their own assessment system. Most of the participants reported that students enjoyed the implemented formative assessment tasks and it enhanced students' attention in classrooms. However, few teachers understood the right approach to practice formative assessment and the practical impact is very minimal.

\subsection{Teachers' Attitude towards Formative Assessment}

The quantitative findings indicate that majority of the respondents portrayed a positive attitude towards the practice of formative assessment. However, from the qualitative findings, the results were mixed. Some of them were positive about the use of formative assessment while some were more cautious about it. The interviewees also revealed that most of the teachers at the participating college were positive about formative assessment, but some were negative due to some reasons which had been highlighted in prior studies by Dijksterhuis et al. (2013), López-Pastor and Sicilia-Camacho (2017), Sach (2012); Winstone \& Millward (2012), and Young \& Jackman (2014). The progressive and open-minded teachers are very positive and try to apply formative assessment in their classes as much as possible. On the other hand, some teachers were being negative toward formative assessment because there are more comfortable with traditional method of assessment as they are not ready to make a drastic change that differs from the norm and they resist to a new system of asessment. Besides they do not have a clear idea of the ways to implement formative assessment appropriately and as a result they lack confidence to apply a new assessment format. The earlier-reviewed study by Young \& Jackman (2014) also indicated this issue.

In some cases, teachers lose their interest in applying formative assessment in their classes because of various difficulties like infrastructural problem, power cut, large classes, etc. These issues are also acknowledged in the study of Muhammad et al. (2019). Nonetheless, research conducted by Sadler (1998), and Umer and Omer (2015) claimed that formative assessment can be implemented successfully in any kind of educational setting. 


\subsection{Importance of Implementing Formative Assessment}

All the interviewees considered formative assessment as a useful tool for enhancing the quality of teaching and learning in higher education especially in Bangladeshi colleges as being agreed by Bennett (2011) and Dochy et al. (1999). They claimed that the standard of assessment and students' results in the final examination were better than before. Interviewees also acknowledged some benefits of formative assessment. During the interviews, it was mentioned that formative assessment allowed them to engage and assess their students throughout the academic year and it also allowed the students to get in-depth knowledge on their course content and overcome their weaknesses. These findings supported the quantitative results. In addition, the interviewed teachers also claimed that it had helped to enhance their students' learning outcomes. Besides, teacher were able to identify different needs of the students with different abilities and fulfil them as much as possible.

Although all the participants were positive towards the implementation of formative assessment, they defer on the way of grading through this type of assessment. Majority of the participants believed that it was necessary to increase the weighting of formative assessment in the overall assessment measure and it must be accompanied with quality feedback. Besides, they also believed that some preconditions for a successful implementation of formative assessment in Bangladeshi colleges had to be fulfilled prior to that. They also suggested that higher levels of transparency among the teachers, and better support from superior and support staff were also essential for a successful implementation of formative assessment. In contrast, some others claimed that the current weighting of assessments were appropriate in the context of Bangladesh.

\subsection{Challenges in Implementing Formative Assessment}

As frequently highlighted in the literature, there are some challenges in implementing formative assessment in Bangladesh higher education institutions. In line with what had been found in prior studies by Alam et al. (2014) and Muhammad et al. (2019), problems such as resource scarcity, infrastructural issues, insufficient power supply, shortage of teachers, large size class and heavy work load of the teachers were cited as some of the challenges that the interviewed teachers were facing when implementing formative assessment in their classrooms. In addition, these teachers also faced some challenges when grading their students using formative assessment (the marks of in-course examination for the Bangladeshi colleges). In this regard, sometimes teachers tend to over-grade favourite students or under-grade unpopular students because of the problems like political pressure, administrative pressure and nepotism. This might hinder the implementation of formative assessment successfully in a larger scale in Bangladeshi colleges.

In Bangladesh, students of different higher educational institutions are largely engaged in political activities. As a result, in many cases teachers have to face huge political pressure while grading a politically active student. Sometimes the pressure comes from the college administration, which can also be due to political pressure from a higher authority. Based on the responses given by teacher participants, the following conceptual framework has emerged: 
Figure 3. Conceptual framework for formative assessment in Bangladeshi Colleges.

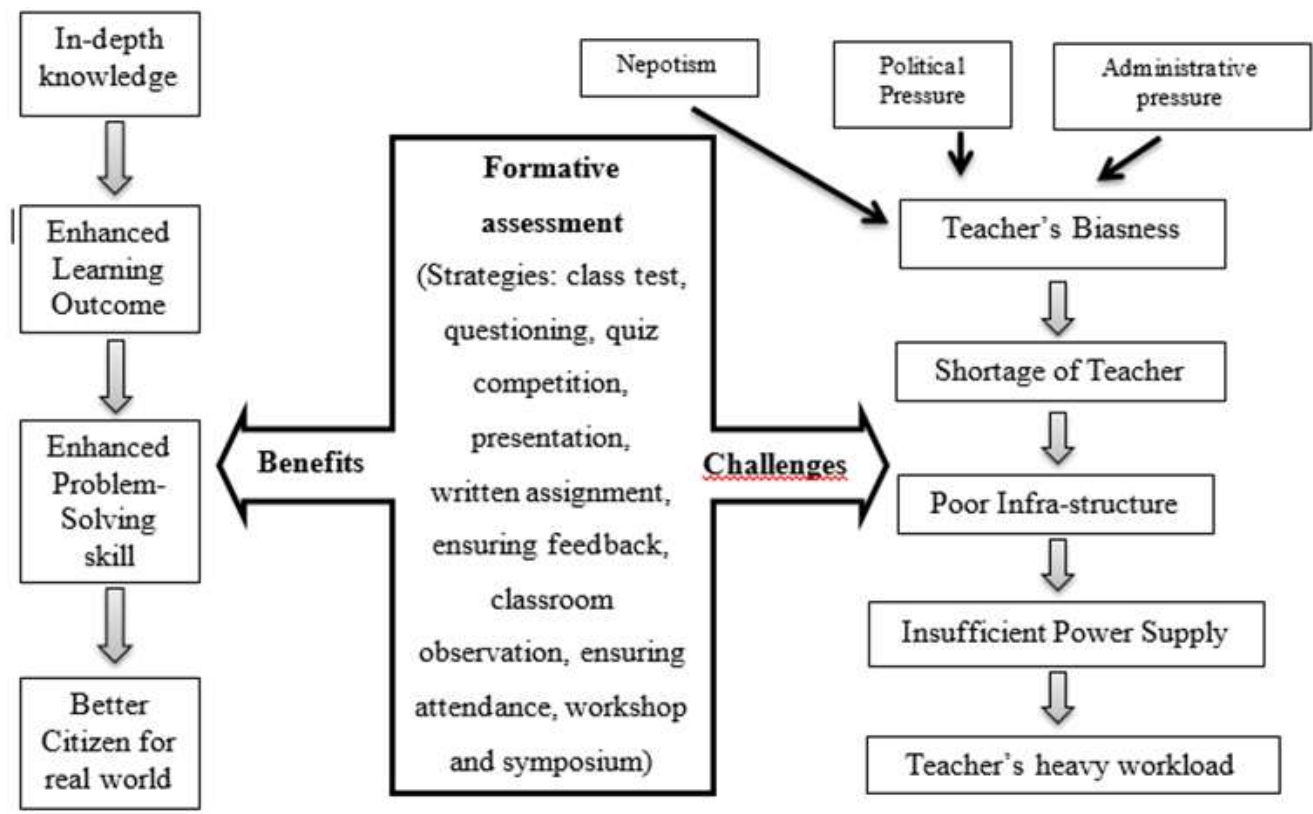

Overall, the above findings reveal that formative assessment is being practised by majority of the respondents. Since the respondents have working experience in other colleges, it could be said, there is a high possibility that other higher educational institutions are also practising some kind of formative assessment but it only carries a small weighting in the overall. To some extent, responses from the interview sessions strengthen the survey findings, which suggest that teachers in this study believe that formative assessment is beneficial for the students and it has a great potential to positively enhance the teaching and learning in Bangladeshi higher education. Nonetheless the effective use of formative assessment is very limited because of the related challenges as depicted in Figure 3.

\section{CONCLUSION}

This study is a mixed-method study exploring the use of formative assessment in a higher education institution in Bangladesh. After analysing the quantitative and qualitative data, it is found that, formative assessment, has become increasingly more common although not being widely used in the context of higher education. In this regard, many teachers take this form of assessment positively in most of the cases. Authors believe that the practice of formative assessment could be enhanced if the highlighted challenges are overcome. These issues and challenges must be addressed accordingly and systematically.

Drawing on the findings of this study, some measures to enhance the formative assessment practice in Bangladeshi higher education institutions should be considered. First, the pressures on teachers have to be minimised to get the best result from formative assessment. Instead, teachers should be empowered or given security from any kind of harm. Secondly, the highlighted resource problems should also be addressed, and a smaller class size is also recommended. In addition, more teachers have to be recruited to reduce the workload of the teachers.

This research is only an initial study to explore the teachers' perception on the formative assessment practice in Bangladeshi higher education institution which will open up a greater avenue for further study on the assessment system. It is our hope that our research will contribute positively to the development of a better assessment system in higher education in 
Bangladesh, which will ultimately contribute to the enhancement of the teaching and learning in Bangladesh higher education.

\section{Declaration of Conflicting Interests and Ethics}

The authors declare no conflict of interest. This research study complies with research publishing ethics. The scientific and legal responsibility for manuscripts published in IJATE belongs to the authors. Ethics Committee Number: The University of Nottingham, EDUC4227-UNMC (Practice Based Inquiry).

\section{Authorship Contribution Statement}

Shamsiah Banu Mohamad Hanefar: Spervision, Methodology, validation, proof-reading, resources, writing Nusrat Zerin Anny: Data collection, investigation, resources writing. Md. Sajedur Rahman: Resources investigation.

\section{Orcid}

Shamsiah Banu Mohamad Hanefar (D) https://orcid.org/0000-0002-3393-1640

Nusrat Zerin Anny (iD https://orcid.org/0000-0001-8559-7157

Md. Sajedur Rahman (D) https://orcid.org/0000-0003-4525-0663

\section{REFERENCES}

Ahmed, P.M., Rahman, P.D.M., Islam, P.D.S. M., Nayeem, P.D.A. I., Khan, P.D. Z.R., Rahman, P.M.H., Islam, M.Z., \& Chackrabartty, S. (2021). Quality and Relevance of Higher Education in Colleges Affiliated with National University Bangladesh: A Bachground Study. https://cedp.gov.bd/wp-content/uploads/2021/03/Quality and Relevance.pdf

Alam, G.M., Mishra, P.K., \& Shahjamal, M.M. (2014). Quality assurance strategies for affiliated institutions of HE : A case study of the affiliates under National University of Bangladesh. Higher Education, (68), 285-301. https://doi.org/10.1007/s10734-0139712-y

Antoniou, P., \& James, M. (2013). Exploring formative assessment in primary school classrooms: Developing a framework of actions and strategies. Educational Assessment, Evaluation, and Accountability, 25(4). https://doi.org/10.1007/s11092-013-918

Azim, F. (2014). Learning promoted by classroom assessment in higher education of Bangladesh: A case study. The International Journal of Social Sciences, 26(1), 165-171.

Begum, M., \& Farooqui, S. (2008). School-based assessment: Will it really change the education scenario in Bangladesh? International Education Studies, 1(2), 45-53. https://doi.org/10.5539/ies.v1n2p45

Bengtsson, M. (2016). How to plan and perform a qualitative study using content analysis. NursingPlus Open, 2, 8-14.

Bennett, R.E. (2011). Formative assessment: A critical review. Assessment in Education: Principles, Policy, and Practice, 18(1), 5-25. https://doi.org/10.1080/0969594X.2010.5 $\underline{13678}$

Bhuiyan, A.K.M.Z.H., \& Hossain, D.M.L. (2017). Quality education at college level institutions: Bangladesh perspective. NAEM Journal, 12(24), 103-112.

Bjornsrud, H., \& Engh, R. (2012). Teamwork to enhance adapted teaching and formative assessment. Policy Futures in Education, 10(4), 402-410. https://doi.org/10.2304/pfie.2 012.10.4.402

Black, P., \& Wiliam, D. (1998). Assessment and Classroom Learning. Assessment in Education: Principles, Policy \& Practice, 5(1), 7-74. https://doi.org/10.1080/09695959 $\underline{80050102}$

Black, P., \& Wiliam, D. (2003). In praise of educational research: Formative assessment. British 
Educational Research Journal, 29(5), 623-637. https://doi.org/10.1080/0141192032000 $\underline{133721}$

Boston, C. (2002). The Concept of Formative Assessment. ERIC Clearinghouse on Assessment and Evaluation College Park MD., 1(1), 1-8. https://doi.org/ED47026, 2002-10-100

Bransford, J.D., Brown, A.L., \& Cocking, R. R. (Eds.). (1999). How people learn: Brain, mind, experience, and school. National Academy Press.

Cagasan, L., Care, E., Robertson, P., \& Luo, R. (2020). Developing a formative assessment protocol to examine formative assessment practices in the Philippines. Educational Assessment, 1-17. https://doi.org/10.1080/10627197.2020.1766960

Clark, I. (2012). Formative assessment: A systematic and artistic process of instruction for supporting school and lifelong learning. Canadian Journal of Education, 35(2), 24-40. https://doi.org/10.1007/s10648-011-9191-6

Clarke, M. (2012). What matters most for student assessment systems: A framework paper. Systems Approach for Better Education Results (SABER) student assessment working paper, no. 1, World Bank. http://documents.worldbank.org/curated/en/21663146814969 1772/What-matters-most-for studentassessment-systems-a-framework-paper

Crooks, T.J. (1988). The impact of classroom evaluation practices on students. Review of Educational Research, 58 (4), 438-481. https://doi.org/10.3102\%2F00346543058004438

Dijksterhuis, M.G.K., Schuwirth, L.W.T., Braat, D.D.M., Teunissen, P.W., \& Scheele, F. (2013). A qualitative study on trainees' and supervisors' perceptions of assessment for learning in postgraduate medical education. Medical Teacher, 35(8). https://doi.org/10.3109/0142159X.2012.756576

Dochy, F., Segers, M., \& Sluijsmans, D. (1999). The use of self-, peer and co-assessment in higher education: A review. Studies in Higher Education, 24(3), 331-350. https://doi.org/10.1080/03075079912331379935

Figa, J.G., Tarekegne, W. M., \& Kebede, M. A. (2020) The practice of formative assessment in Ethiopian secondary school curriculum implementation: The case of West Arsi Zone Secondary Schools. Educational Assessment, 25(4), 276-287. https://doi.org/10.1080/10 $\underline{627197.2020 .1766958}$

Gikandi, J.W., Morrow, D., \& Davis, N.E. (2011). Online formative assessment in higher education: A review of the literature. Computers and Education, 57(4), 2333-2351. https://doi.org/10.1016/j.compedu.2011.06.004

Haque, M., Yousuf, R., Abu Bakar, S.M., \& Salam, A. (2013). Assessment in undergraduate medical education: Bangladesh perspectives. Bangladesh Journal of Medical Science, 12(4), 357-363. https://doi.org/10.3329/bjms.v12i4.16658

Harlen, W. \& James, M. (1997). Assessment and learning: Differences and relationships between formative and summative assessment. Assessment in Education: Principles, Policy \& Practice, 4(3), 365-379. https://doi.org/10.1080/0969594970040304

Jeffrey A. Barney \& Robert McCowens. (2009). Review of transformative assessment by W. James Popham. Association for Supervision and Curriculum Development, 6(12), 137138. https://doi.org/ISBN-978-1-4166-0667-3

Klenowski, V. (2009). Assessment for learning revisited: An Asia- Pacific perspective. Assessment in Education: Principles, Policy and Practice, 16(3), 263-268. https://doi.org/10.1080/09695940903319646

López-Pastor, V., \& Sicilia-Camacho, A. (2017). Formative and shared assessment in higher education. Lessons learned and challenges for the future. Assessment and Evaluation in Higher Education, 42(1), 77-97. https://doi.org/10.1080/02602938.2015.1083535

Mahmud, M. (2019). Quality and Relevance of Higher Education in Bangladesh. BIDS Critical Conversations 2019. Bangladesh Institute of Development Studies.

Mamun-ur-Rashid, M., \& Rhman, M.Z. (2017). Quality of higher education in Bangladesh: 
Application of a modified SERVQUAL model. Problems of Education in the 21st Century, 75(1), 72-91. https://doi.org/10.33225/pec/17.75.72

Monem, M., \& Baniamin, H.M. (2010). Higher education in Bangladesh : Status, issues, and prospects. Pakistan Journal of Social Sciences (PJSS), 30(2), 293-305.

Al Faruki, M., J., Haque, M.A., \& Islam, M.M. (2019). Student-centered learning and current practice in Bangladeshi college education. Journal of Education and Practice, 10(13), 95107. https://doi.10.7176/JEP/10-13-11

Ngendahayo, E. (2014). Rethinking Rwandan higher education assessment system and approaches. Rwandan Journal of Education, 2(2), 31-47.

Nicol, D., \& MacFarlane-Dick, D. (2006). Formative assessment and self-regulated learning: A model and seven principles of good feedback practice. Studies in Higher Education, 31(2), 199-218. https://doi.org/10.1080/03075070600572090

Ozan, C., \& Kincal, R.Y. (2018). The effects of formative assessment on academic achievement, attitudes toward the lesson, and self-regulation skills. Educational Sciences: Theory \& Practice, 18(1), 85-118. https://doi.org/10.12738/estp.2018.1.0216

Paul, B.K., Sarkar, S., Nandi, S., Alim, M.A., Biswas, S.K., \& Rahman, M.A. (2016). Changing teaching through formative assessment: A review. Bangladesh Medical Journal, 45(1), 47-53. https://doi.org/10.3329/bmj.v45i1.28968

Pintrich P.R., \& Zusho A. (2002) Student motivation and self-regulated learning in the college classroom. In: Smart J.C., \& Tierney W.G. (eds). Higher Education: Handbook of Theory and Research, 17. Springer. https://doi.org/10.1007/978-94-010-0245-5_2

Rabiul, I. (2014). Higher education in Bangladesh : Diversity, quality and accessibility. First National Education Conference on Whither Policy Reform in Education: Lessons and Challenges, (November), 1-16.

Rahman, K.A., Hasan, M.K., Namaziandost, E., \& Ibna Seraj, P. M. (2021). Implementing a formative assessment model at the secondary schools: attitudes and challenges. Language Testing in Asia, 11(1). https://doi.org/10.1186/s40468-021-00136-3

Rahman, T., Nakata, S., Yoko, N., Mokhlesur, R.M., Uttam, S., \& Rahman Asahabur, M. (2019). Bangladesh Tertiary Education Sector Review. World Bank.

Riaz, F., Yasmin, S., \& Yasmin, R. (2015). Introducing regular formative assessment to enhance learning among dental students at Islamic International Dental College. Journal of the Pakistan Medical Association, 65(12), 1277-1282.

Roos, B., \& Hamilton, D. (2005). Formative assessment: A cybernetic viewpoint. Assessment in Education: Principles, Policy \& Practice, 12(1), 7-20. https://doi.org/10.1080/09695 94042000333887

Ruiz-Primo, M.A. (2011). Informal formative assessment: The role of instructional dialogues in assessing students' learning. Studies in Educational Evaluation, 37(1), 15-24. https://doi.org/10.1016/j.stueduc.2011.04.003

Sach, E. (2012). Teachers and testing: An investigation into teachers' perceptions of formative assessment. Educational Studies, 38(3), 261-276. https://doi.org/10.1080/03055698.201 1.598684

Sadler, D.R. (1989). Formative assessment and the design of instructional systems. Instructional Science, 18(2), 119-144. https://doi.org/10.1007/BF00117714

Sadler, D. R. (1998). Formative Assessment: revisiting the territory. Assessment in Education: Principles, Policy \& Practice, 5(1), 77-84. https://doi.org/10.1080/0969595980050104

Shahidul, H.M.M. (2016). Rethinking higher education. The Daily Star.

Sharma, S., Sharma, V., Sharma, M., Awasthi, B., \& Chaudhary, S. (2015). Formative assessment in postgraduate medical education - Perceptions of students and teachers. International Journal of Applied \& Basic Medical Research, 5(Suppl 1), S66-S70. https://doi.org/10.4103/2229-516X.162282 
Umer, M., \& Attayib Omer, A.M. (2015). An investigation of Saudi English: Major learners' perceptions of formative assessment tasks and their learning. English Language Teaching, 8(2), 109-115. https://doi.org/10.5539/elt.v8n2p109

Wang, K.H., Wang, T.H., Wang, W.L., \& Huang, S.C. (2006). Learning styles and formative assessment strategy: Enhancing student achievement in Web-based learning. Journal of Computer Assisted Learning, 22(3), 207-217. https://doi.org/10.1111/j.13652729.2006.00166.x

Wiliam, D. (2011). What is assessment for learning?. Studies in Educational Evaluation. 37(1), 3-14. https://doi.org/10.1016/j.stueduc.2011.03.001

William, D. (2014). Formative assessment and contingency in the regulation of learning processes. Toward a Theory of Classroom Assessment as the Regulation of Learning, (April). Philadelphia, USA.

Winstone, N., \& Millward, L. (2012). Reframing Perceptions of the Lecture from Challenges to Opportunities: Embedding Active Learning and Formative Assessment into the Teaching of Large Classes. Psychology Teaching Review, 18(2), 31-41.

World Bank. (2013). Systems Approach for Better Education Results (SABER) reports.

Yorke, M. (2003). Formative assessment in higher education: Moves towards theory and the enhancement of pedagogic practice. Higher Education, 45, 477-501.

Young, J.E.J., \& Jackman, M.G.A. (2014). Formative assessment in the Grenadian lower secondary school: teachers' perceptions, attitudes and practices. Assessment in Education: Principles, Policy and Practice, 21(4), 398-411. https://doi.org/10.1080/096 $\underline{9594 X .2014 .919248}$ 